\title{
1896年ブダペスト建国千年祭博覧会の会場計画について ON THE SITE PLANNING FOR THE MILLENNIUM EXHIBITION IN BUDAPEST 1896
}

\author{
水野貴博*
}

Takahiro MIZUNO

\begin{abstract}
In the $19^{\text {th }}$ century Budapest, two exhibitions were held in the park Városliget. For the first exhibition in 1885, Industry Pavilion was built as the main building at the center of the axial structure of the site, but for the Millennium Exhibition in 1896, History Pavilion, the new main building, should be emphasized more than Industry Pavilion. To solve this problem, a new entrance was planned at the end of Andrássy Street, a radial street which connected the center of the city and the park, and a promenade circuit was introduced to connect all major pavilions in the site. History Pavilion was built as a complex of imitations of several historic buildings in Hungary and placed picturesquely on an island in a lake. After the exhibition, a square was formed at the entrance and the History Pavilion was rebuilt as a durable building. The adoption of a promenade circuit as the main traffic line and an asymmetric picturesque building as the main pavilion was a unique solution at the time, since most of the sites of the world exhibitions in the $19^{\text {th }}$ century were based on classical symmetrical layout.
\end{abstract}

Keywords : Budapest, Millennium Exhibition, Site Planning, Folly Castle, Circuit Style Planning, Worlds Columbian Exposition ブダペスト，建国千年祭博覧会，会場計画，模擬城，回遊式計画，シカゴ万国博覧会

\section{1. はじめに}

建国千年祭博覽会は、マジャル人がカルパチア盆地に定住して千 周年 1)を記念する行事として 1896 年 5 月 2 日から 11 月 3 日までブ ダペストで開催された博覧会である。記念行事と博覧会を結びつけ る提案はハンガリー工業連盟(Országos Iparegyesület)議長ジチ・ イェネー(Zichy Jenó)によって1891 年になされ、当初は万国博覧会 としての開催が検討されていたが、最終的には準備期間も考慮され、 国内博覧会となった。2)一般的な博覧会に見られる産業の進展や世 界各地の文物の展示よりも、ハンガリーの歴史や文化に関する回顧 的な展示に力が注がれ、内外にアピールされた。

この博覽会は単なる一過性のイベントに留まらず、ブダペストの 近代化の画期となっている。1890 年代のハンガリーでは好景気に支 えられて多くの公共建築や都市基盤の整備が進められており、3)都 市整備がこの博覧会の開催と関連づけられて構想されたこともあっ た。4)博覧会後には跡地や周辺の整備も進められた。

また、この会場計画には 19 世紀に他の欧米諸国で開かれていた 万国博覧会の計画に倣っている点もあるが、同時代の産業よりも民 族の歴史を重要なテーマとして扱った博覧会の特殊な性格のため、 それまでの外国の博覧会には見られない解決が図られている。

この博覽会の会場に関する先行研究としては、敷地選定までの過 程を解明し、会場となった公園の中の橋や遊歩道などの整備をこの 博覽会の成果とした Sisa József によるものがある。5)しか、この
研究は博覧会場計画の成立過程やその意義についての分析には立ち 入っていない。

そこで、本研究は、会場計画の成立経緯と設計理念、会場からそ の後の跡地の整備に受け継がれた点を明らかにし、さらに 19 世紀 から 20 世紀にかけての他国の博覧会場計画 ${ }^{6)}$ との関係を考察し、博 覧会場の計画史の中に位置づけることを目的とする。

\section{2. ヴァーロシュリゲトと 1885 年の博覧会}

建国千年祭博覧会の会場となった公園ヴァーロシュリゲトは、市 の北東に位置している。1813-16 年にフランス出身の庭園家ネビエ ン・ヘンリク(Nebbien Henrik)によって整備された。(図 1) 都心か らのメインアクセスであったキラーイ通り（途中から幅広くなって ヴァーロシュリゲティ・ファショルと名称が変わる）の延長上に円 形広場が建設され、遊歩道と湖が整備され、19 世紀の市民の行楽地 となった。7)

キラーイ通りは都心部で幅が狭かったため、1872-76 年にはこれ とほぼ並行する幅広い計画道路アンドラーシ通りがヴァーロシュリ ゲトへの新たな交通路として建設された。(図 2) しかし、アンドラ ーシ通りの延長上には湖があって公園内に直進できないため、人の 流れを導くために、1881 年に通りの終点から右に向かい、円形広場 の背後を通って、公園外の競馬場に向かうシュテファーニア通りが 建設された。そのため、アンドラーシ通りの完成後も円形広場付近

本論文は，拙論『重君主制時代のブダペストの都市計画に関する研究』(東京大学学位論文，2007)第6 章に新たに分析を加えて再構成したものである。

* 跡見学園女子大学＼cjkstart兼任講師・博士(工学)－Part-time Lecturer, Atomi Univ., Dr. Eng. 
がヴァーロシュリゲトの中心的空間であり続けていた。

ヴァーロシュリゲトでは1885年にも国内博覧会が開かれている。

（図 3）この博覽会は「産業館」をメインパヴィリオンとし、産業 や技術に関する展示を主としたものであった。会場はヴァーロシュ リゲト内のシュテファーニア通りと湖より奥の地区（以下、本論文

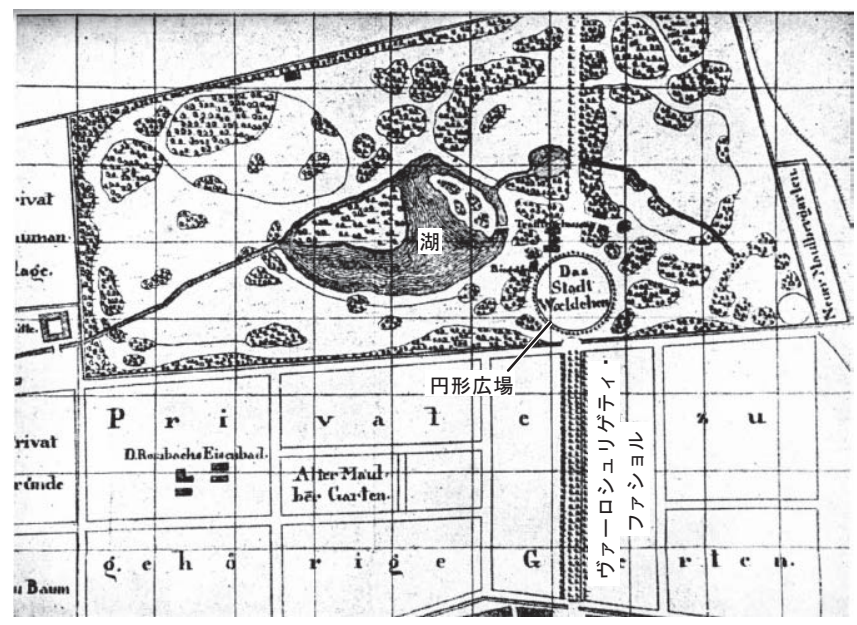

図1 1827 年のヴァーロシュリゲト

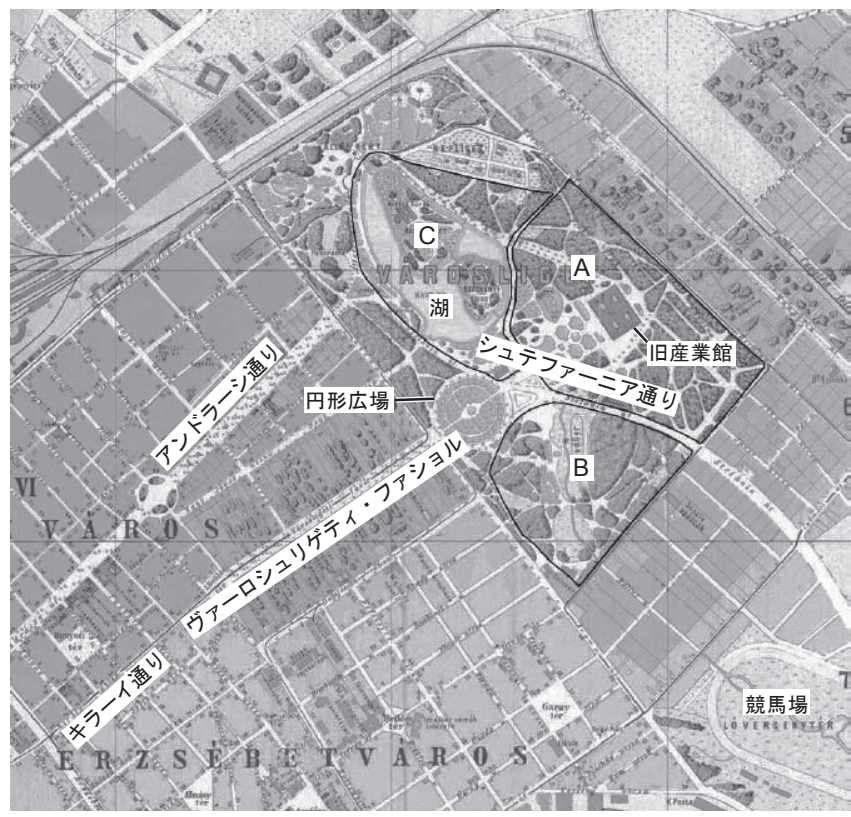

図 21896 年のヴァーロシュリゲト

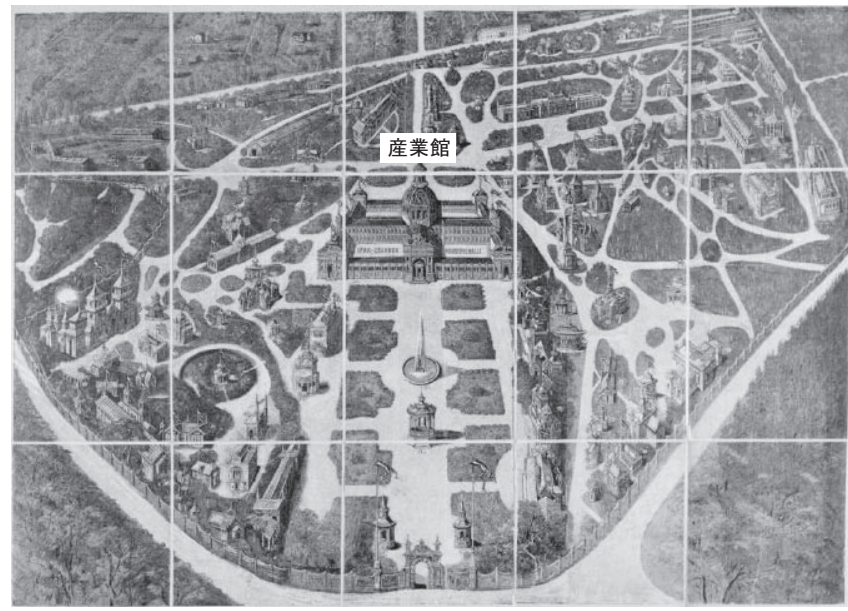

図 31885 年の博覧会場
では $\mathrm{A}$ 地区と呼ぶ。図 2 参照）で、ヴァーロシュリゲティ・ファシ ヨルの軸線の延長上に産業館を配置し、その手前を整形式庭園、左 右にその他の小さなパヴィリオンを配置したものであった。産業館 をはじめとしていくつかのパヴィリオンが恒久的建造物として建設 され、博覧会後も残された。8)

\section{3. 会場計画設計競技}

\section{1 会場決定と設計競技課題}

建国千年祭博覧会の会場については、1892 年 8-9 月に博覧会実施 委員会の分科委員会で協議が行われた。当初は市の中心を流れるド ナウ川沿いでの開催も検討されたが、結局再びヴァーロシュリゲト が会場になり、1885 年の会場であった A 地区に加えて、シュテフ アーニア通りを挟んだ地区（以下、B 地区とする）も敷地に含めら れることになった。9)この敷地を対象に 1893 年 2 月 8 日から 3 月 31 日まで、会場計画の設計競技が行われた。

1891 年に万国博覧会として提案された段階から、ハンガリーの 「歴史、文化、経済の活力と能力を示す」ことがこの博覧会の目的 として掲げられていた。10)そのため、「歴史館」がメインパヴィリオ ンと位置づけられ、会場計画と同時に歴史館の設計競技も発表され た。11)

この会場計画設計競技のプログラム 12)では、ヴァーロシュリゲト 内に公園として残す部分を確保すること、植栽を可能な限り維持す ること、博覧会の開催中もシュテファーニア通りの自由通行を可能 とし、通りの両側の会場を歩道橋で結ぶこと、1885 年博覧会のパヴ イリオンを別の用途で再利用すること、実施委員会が建設するパヴ イリオン 13)以外に、市や企業のパヴィリオン、ホテルやカフェなど を配置する敷地、式典のための最低 2 万人を収容できる広場を確保 することが求められた。これらの条件を踏まえた上で、既定の $\mathrm{A}, \mathrm{B}$ 地区以外に隣接する地区を敷地に含めることも認められていた。

\section{2 応募各案と審査員の評価}

応募者は配置図に建物、道、緑地などを示し、解説書を添付する ことが求められた。計 34 案が到着し、うち 4 案が入選とされたが、 1位は設けられなかった。14)

各案の特徴とそれに対する審査員の評価 15) は以下のようなもの であつた。

ギエルグル・カールマーン(Giergl Kálmán)とコルブ・フローリ シュ(Korb Flóris)による案（図 4）は、円形広場に接するように半 円形の広場を設け、そこから放射状にパヴィリオンを配置している 点に特徵がある。歴史館は $\mathrm{A}$ 地区の中心軸線から90 度右に曲がっ た方向にある B 地区の中心軸線上に配置されていた。

ゲルシュテル・カールマーン(Gerster Kálmán)、ミルコフスキ・ ゲーザ(Mirkovszky Géza)による案（図 5）は、産業館の前後にアー ケードに囲まれたモニュメンタルな中庭を提案し、式典のための空 間としている。さらに、円形広場も会場に含め、その中央に歴史館 を配置していた。しかし、そのためにシュテファーニア通りを円形 広場の手前を通るよう捻じ曲げてしまった点、敷地の現状を考慮せ ずに公園を大規模に改造している点が審査評で批判されている。

建設会社「ノイシュロス・カーロイと息子」(Neuschloss Károly és fia)の案（図 6) は、会場を拡大して湖とその中の島も敷地に含めて いた。（以下、この湖周辺を $\mathrm{C}$ 地区と呼ぶ）この案の特徴は、アン 


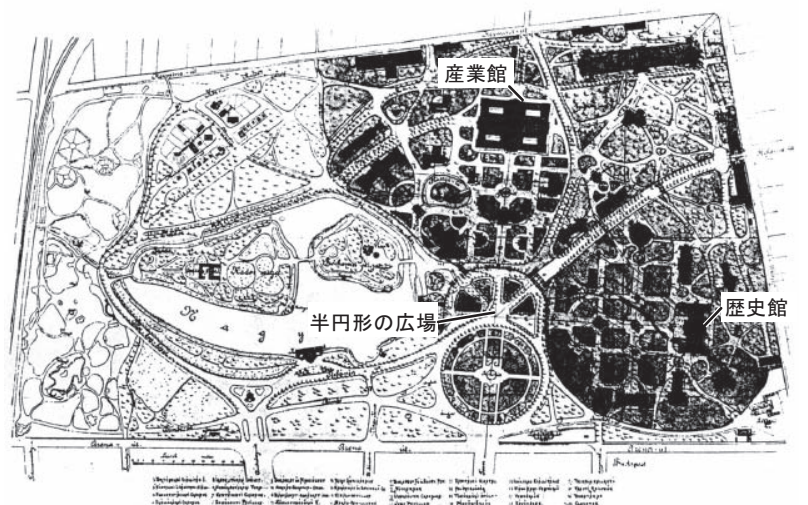

図 4 設計競技ギエルグル\&コルブ案

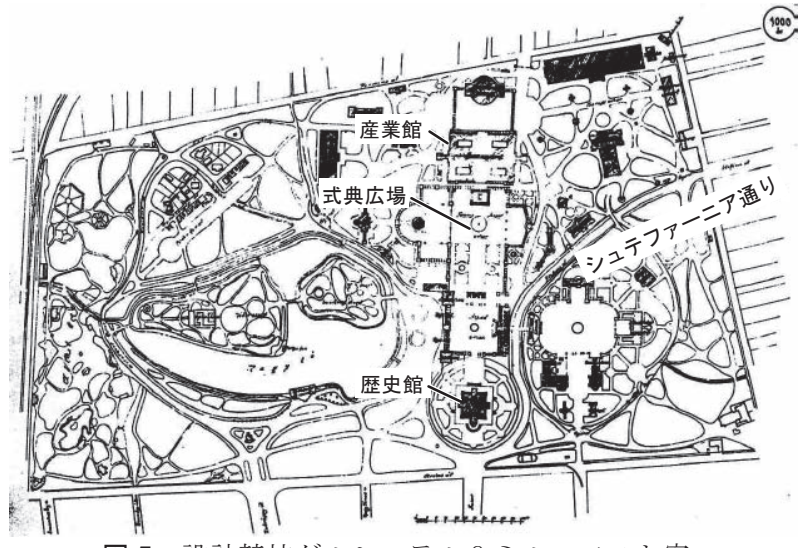

図 5 設計競技ゲルシュテル \&ミルコフスキ案

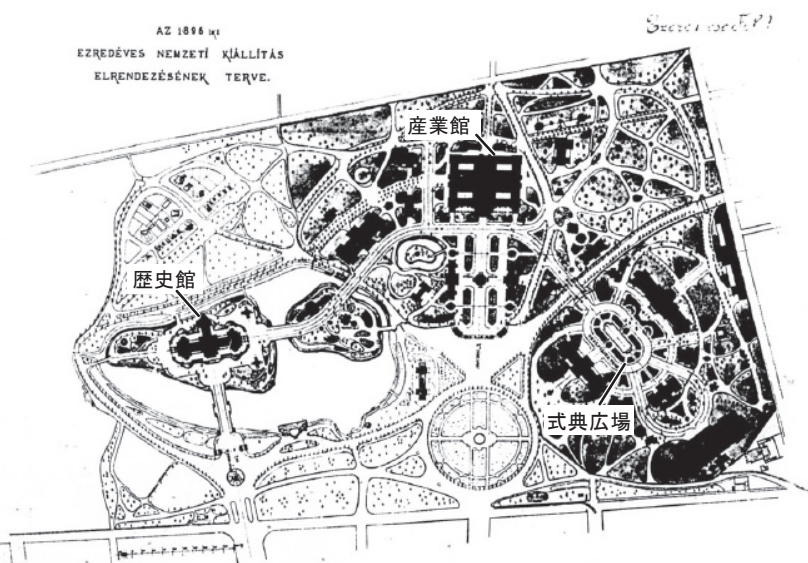

図 6 設計競技ノイシュロス案

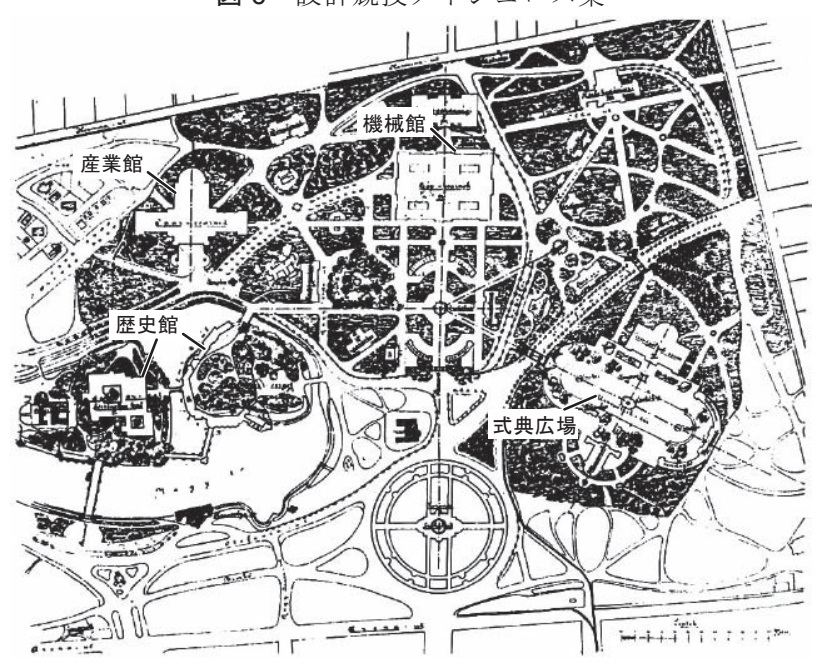

図 7 設計競技シッケダンツ案
ドラーシ通りの軸線延長上にもエントランスを設け、その延長上の 島の中に歴史館を配置していたことである。A 地区は産業館、B 地 区は式典広場を中心に構成し、各地区を曲線の遊歩道で繋ぐことも 計画していた。審査評はこの計画の全体を高く評価しているが、難 点の一つとして歴史館が提案されている敷地に既存の温泉施設 ${ }^{16)}$ がある点を挙げ、この施設の取り壊しは認められないとしている。

シッケダンツ・アルベルト(Schickedanz Albert)による案（図 7) も、C 地区を敷地に含めていた。旧産業館を機械館とし、C 地区の 湖の背後に新産業館をメインアクセスの軸線と平行して配置してい た。B 地区ではエントランスの広場から斜めに延びた軸線上に配置 し、式典空間としていた。いくつかのパヴィリオンへのアプローチ が明快でない点について審査評は否定的であった。しかし、この案 の最大の特徴は歴史館を湖の中の二つの島にそれぞれ修道院と城塞 のような形状で配置していたことである。審査評はこの構想を「生 き生きとした水との関係をもたらした」と高く評価し、アンドラー シ通りから橋を渡ってアクセスできる点も利点と認めている。シッ ケダンツは、並行して行われていた歴史館の設計競技でも同じコン セプトの建物を提案し、入選 4 案のうちに選ばれている。17)

\section{3 審査過程で注目された点}

この設計競技で当初指定された敷地では、明らかに 1885 年博覧 会の旧産業館が最も中心的な位置を占めていた。しかし、建国千年 祭博覧会のメインパヴィリオンは新たに建設する歴史館であり、こ れをいかにして旧産業館より強調するかが会場配置計画の重要なポ イントであったことが、各案に対する審査評から推察できる。

また、審査評から、ノイシュロス案の全体計画とシッケダンツ案 の歴史館の形状の評価が特に高かったことが理解できる。

ギエルグル＆コルブ案では、アプローチのシュテファーニア通り から A, B 両地区それぞれに平等にアクセスできるようにし、歴史館 は B 地区の中心パヴィリオンとされた。しかし、B 地区は A 地区に 比べて小さいため、やはり旧産業館以上に強調することはできない。 ゲルシュテル\&ミルコフスキ案は、歴史館を旧産業館より市内に近 い位置に配置することでこの問題を解決しようとしたが、そのため にはシュテファーニア通りの経路変更が必要になる。ノイシュロス 案は旧産業館の軸線とは別に、市内からのアクセスとなるアンドラ ーシ通りの軸線上にメインエントランスを設け、その延長上の C 地 区に歴史館を配置することで、この問題を解決したが、既存の温泉 施設を取り壞さなければこの計画は実現不可能であった。

ノイシュロス案の問題点を解決する鍵となるのがシッケダンツ案 であった。敷地条件を生かして歴史館を湖の上の左右非対称の建物 として計画することで、軸線上に配置しなくても十分印象的なメイ ンパヴィリオンになり得ることに審查員は注目したと考えられる。 このような着眼点は最終的な会場計画に引き継がれている。

\section{4. 最終計画の決定}

4.1 審査委員会による会場計画の作成

設計競技が締め切られた直後の 4 月 5 日、商業大臣のルカーチ・ ベーラ(Lukács Béla)が、B 地区の代わりに C 地区を利用できない か、ブダペスト市議会で提案した。18)市議会は、博覧会場に恒久的 な建物を建設しないことなどを条件に、この提案を承認した。

審查委員会はこの承認を確認して上記の 4 案を入選とした。そし 
て、審査員の構成員のうち建築家や都市計画家を中心とした 5 名 ${ }^{19)}$ からなる分科委員会を設け、この委員会に B 地区の替わりに C 地区 を会場に含め、当選 4 案のよい点を元に会場配置案を作成させた。

審査委員会は、5 月 10 日付の建築専門紙“Bauzeitung für Ungarn”で分科委員会作成の案の設計コンセプト20)を発表した。そ の内容は、その後 5 月 31 日に博覧会実施委員会で承認され、建築 専門各紙 21)で発表された図面（図 8）とほぼ合致している。温泉施 設を除く $\mathrm{C}$ 地区が会場に含められ、 $\mathrm{B}$ 地区は公園のまま維持される ことになった。

\section{2 審査委員会案と設計競技入選案との比較}

審査委員会の発表した案には、各案のアイデアを単なる組み合わ せではなく、独自の一貫した理念を認めることができる。上述の設 計コンセプトと図面から、この案が応募各案から引き継いだ点と審 査委員会が新たに構想した点を確認寸る。

\subsection{1 会場のエントランスと環状の動線計画}

審查委員会案は、円形広場の奥の旧会場の入り口を第二エントラ ンスとし、アンドラーシ通りの延長上に新たなメインエントランス を設けていた。会場のメインエントランスはアンドラーシ通りの軸 線の延長上、ナードル島（左側の島）の向かいに移される。なぜな ら、各地区へのアクセスが容易になり、外観上の効果も非常に高め られるからである。メインエントランスとナードル島を幅広い橋で 結ぶことで、大量の人波となった訪問客を適切に導くことができ る。」(括弧内引用者) としており、会場への主要動線となるアンド ラーシ通りの延長上に入口を設ける合理性を述べている。

また、審査委員会案は会場内に環状の遊歩道を設けていた。設計 コンセプトでは「メインエントランスの前、すなわち出口にも当た る広場からは、幅広い環状道路が博覧会場全体に配置されなくては ならない。計画の環状道路では、二手に分かれた道の片方が産業館 の前を、もう片方がその背後を通ることになる。博覧会の見学をで きる限り体系的にするために、重要な建造物はこの道沿いに建設さ れなければならない。」と述べられており、この遊歩道を巡回路とし て想定した、いわば回遊式の会場構成が提案されている。

ナードル島には国王の控え室となる「国王のパヴィリオン」を中 心にした広場が設けられ、ここから環状道路が分岐している。温泉 施設の取り壊しを避けるため、この国王のパヴィリオンへのアプロ 一チはアンドラーシ通りの軸線上ではなく少し右に振れているが、 このカーブがそのまま環状道路の曲線に繋がっている。また、池の 形状に手を加え、ナードル島の背後を堰き止めて会場の他の部分に 繋げている。

設計競技のノイシュロス案もアンドラーシ通りの軸線上にエント ランスを設け、会場内の各地区を曲線の遊歩道で結んでいたが、歴 史館の脇から始まる遊歩道はエントランスからの動線と適切に結ば れておらず、また式典広場で行き止まりになっていた。これに対し、 審査委員会案の環状道路はメインエントランスから一筆書きするよ うに会場を周回し、人の流れを無理なく導いている。この動線計画 は、審查委員会案が独自に展開させたものと考えられる。

また、審査委員会案では、アンドラーシ通りの延長上が第一エン トランスに位置づけられ、会場の主要動線が環状道路とされている ことから、設計競技 4 案のいずれと比べても円形広場の軸線の中心 性が弱められていることが理解できる。

\subsection{2 湖の島の歴史館}

島の上には歴史館を配置している。コンセプトでは「歴史部門の 展示はセーチェニ島 (右側の島)の城と要塞に似た建物で行われる。 この島と周辺地区はハンガリーの発展の主な時期を反映した建物を 建設するための場所とされ、これらの建物は島の内外の会場区画に 素晴らしい眺望の効果をもたらすものである。」（括弧内引用者）と し、会場内でこれよりも適切な場所はないとも述べている。

さらに、「これら島々の絵画的な配置と池を会場に含めることが、 記念祭に際して他では得られない効果を確実にする」と、池と島を 会場に含むことによってピクチュアレスクな効果が得られることが 強調されている。

この島の上の城塞を模したパヴィリオンの構想はシッケダンツ案 を反映している。歴史上の各時代を建物の形状に反映させるという 展示コンセプトも、シッケダンツが歴史館の方の設計競技で述べて いた主張で、彼の構想がほぼ受け入れられたと理解できる。

ただし、シッケダンツが左右二つの島を歴史館の敷地に想定して いたのに対し、審査委員会案では規模を縮小し、セーチェニ島だけ を用いている。シッケダンツがナードル島に計画していた修道院を セーチェニ島に移し、セーチェニ島全体に想定していた城塞を縮小 し、環状道路を挟むよう両者を配置することにより、狭い島の上で パヴィリオンへのアクセスと会場内の循環交通を両立させている。

\section{2 .3 博覧会場内のゾーニング}

審査委員会案は上記のようにメインエントランスをアンドラーシ 通りの軸線上に設け、歴史館を池の中に配置することで、歴史館を 産業館よりも強調するという設計競技の課題に対してどの応募案よ りも適切に回答していた。

これに加え、審査委員会案のコンセプトは展示内容に基づく会場 内の配置計画を強調していた。展示は歴史、民俗学、農業、産業、 技術、芸術の 6 部門に分けられ、それぞれ図 8 のように位置が指定 されていた。産業館は 1885 年の博覧会の旧産業館がそのまま再利 用された。なお、民俗学部門は設計競技課題発表と実施計画図作成 の間に展示構想が変わり、博覧会の中での重要度が増していた。当 初のプログラムでは「民俗学・家内産業館」という一棟のパヴィリ オンが想定されていたものが、各地方の農村建築を再現した一つの 村をつくり、建物自体も展示物とする計画に変わっている。22)また、 芸術館は博覧会場の外のアンドラーシ通りにできるだけ近い位置に 恒久的建造物として建設し、博覧会後も美術館として利用すること が構想されていた。23)

コンセプトではこの配置の背景となる構想について詳細には述べ られていないが、6 部門の配置は歴史、民俗学、芸術というハンガ リーの文化に関する展示、それ以外の同時代の産業に関する展示に 分類でき、前者は $\mathrm{C}$ 地区とその周辺、後者は $\mathrm{A}$ 地区の旧博覧会場に ほぼ該当している。歴史館を中心としたハンガリー文化展示と産業 館を中心とする産業展示の二つを柱とし、文化展示をより重視する という博覧会の理念を、関連する展示を集め、文化展示をメインエ ントランス近くに配することでより鮮明に表現している。

当時の新聞もこの特性を的確に捉えており、「この博覧会の主催者 たちは雛形を模倣するのではなく、歴史的視点と博覧会一般の現代 的視点という、この博覽会の特徴の両方を表現するような新しい興 味深い計画を提案し、博覧会後のヴァーロシュリゲトの地位向上に 
も重点を置いている。」24) と論評していた。

以上のように、審查委員会案は設計競技の応募各案を参考にしな がらも、応募案のいずれよりも完成度の高い新しい構想を示してい た。環状道路を巡回寸る会場計画、湖の島のピクチュアレスクなメ インパヴィリオンを採用することで、1885 年の博覧会場を含む敷地 を全く新しい構成に書き換えることに成功したといえよう。

\section{3 審査委員会案から建設までの間の改変}

審查委員会による図は実際に建設された会場（図 9,10）にほぼ引 き継がれた。それでも実現までの間に若干の変更が見られる。

博覽会実施委員会と市の協議の結果、C 地区が広げられ、25)湖周 辺に水に関係のあるパヴィリオン 26)が配置された。

また、道路の幅や形状にも若干の変更が見られる。環状道路はア

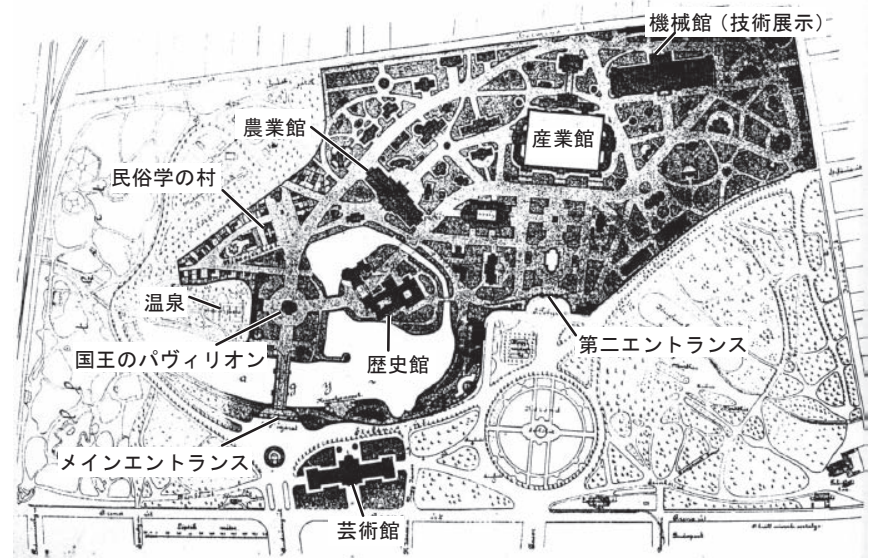

図 $8 \quad 1893$ 年の分科委員会作成の会場計画図

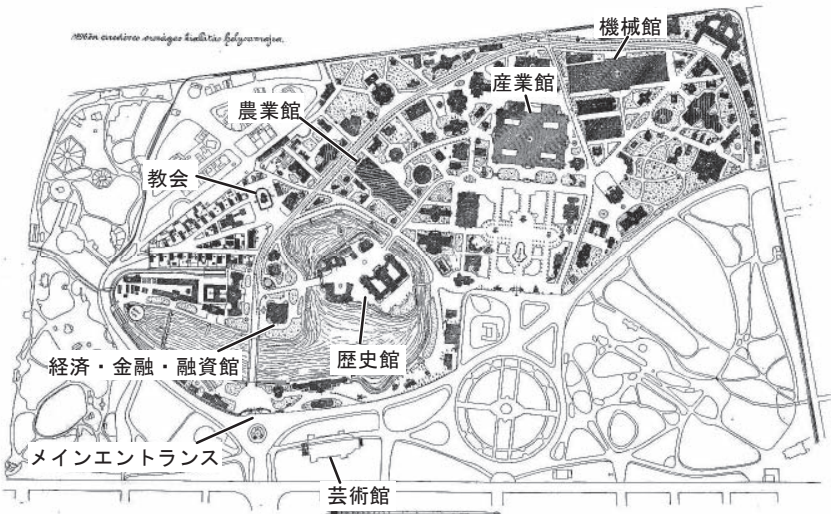

図 9 建国千年祭博覧会場図

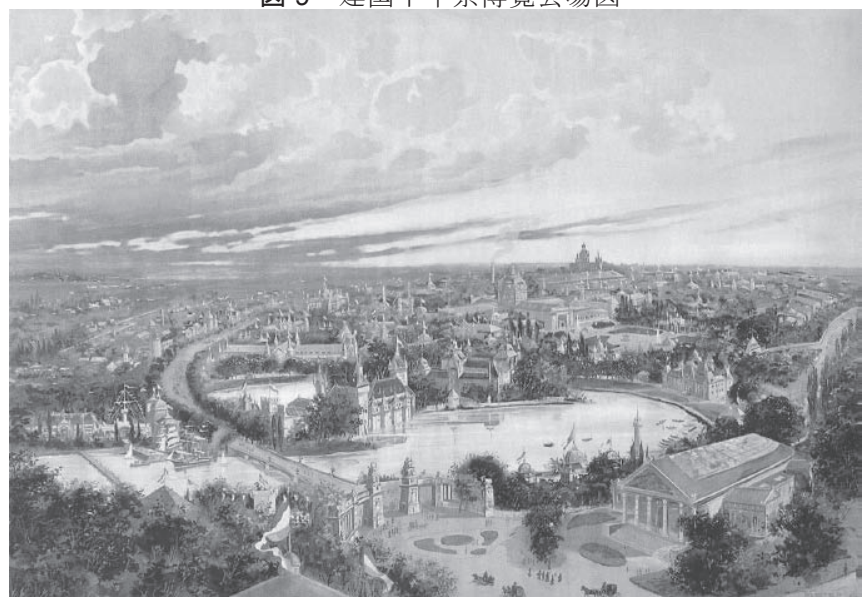

図 10 建国千年祭博覧会場鳥瞰図
プローチからほぼ直進して会場の奥に向かう道と分岐して歴史館の 間を通って産業館に向かう道の幅に差が付けられ、前者が主要動線 とされている。また、農業館、機械館などいくつかの左右対称の大 きなパヴィリオンの前にあるアプローチの幅が狭められ、軸性が弱 められている。

変更点の中でも会場全体の印象に特に影響を与えたのは、いくつ かのパヴィリオンの配置と、審查委員会案の段階ではまだ決定され ていなかったいくつかのパヴィリオンの形状であろう。

当初、環状道路の分岐点に想定されていた国王のパヴィリオンは 実際には建設されず、国王の控え室は最終的に歴史館の中に設けら れた。27)同位置にはこれに代わる象徵的な建物は配されなかったが、 民俗学部門の村の教会（図 11）が、エントランスから橋を渡る道筋 からの視線のほぼ延長上に配置されている。1893 年の計画図では教 会らしき建物がもう少し奥まった位置に描かれているため、遊歩道 からの眺めを意識して計画を変更したことも推測できる。この教会 はカロタセグ地方 28)マジャルヴァルコー(Magyarvalkó)村のカルヴ アン派教会を模したもの 29)であるが、四隅に小塔を配した急勾配の 塔に特徴があり、遊歩道を進む人々の目を引くアクセントとなった と考えられる。

メインエントランスから進んで湖の対岸に見える目立つ位置に、 当初の建設予定にはなかった経済・金融・融資館が配置されている。 歴史や民俗学の文化展示が中心のこの地区への配置は適切でないよ うに見えるが、建築専門紙の紹介では「この展示は、経済・金融・ 融資の歷史的発展を示寸博覧会で示寸初めての試みである。そして これまでのこの種の展示と異なり、幸いにも千年祭の歴史の枠組み にもふさわしいものである。」30）(強調原文）とされており、この配 置の妥当性が強調されている。このパヴィリオンではかつてハンガ リーの経済の中心地だったことを理由に、現スロヴァキアやトラン シルヴァニアの歴史的建造物の形状が引用されていた。（図 12）31) このような歴史的建造物からの引用は、歴史館（図 13）を踏襲した ものと考えられる。

これらの改変を経て、文化展示の C 地区には実在する歴史的建造 物やヴァナキュラー建築の形状を引用したパヴィリオンが集中した。 湖越しや曲線の遊歩道沿いにさまざまな形状のパヴィリオンの織り な寸景観が展開し、左右対称のパヴィリオンが並ぶ産業展示の $\mathrm{A}$ 地 区との対比がより際立つようになった。

\section{5. 建国千年祭博覧会後のヴァーロシュリゲト整備}

本章では、博覧会後のヴァーロシュリゲトの整備について分析し、 会場計画がこの公園の整備に及ぼした影響を考察する。

\section{1 英雄広場の形成}

建国千年祭博覧会後、会場のメインエントランス付近は「英雄広 場」(Hősök tere)に整備された。（図 14）この広場は、高い円柱と 背後の四分円のコロネードを組み合わせた「建国千年記念碑」 (1894-1929)がアンドラーシ通りの軸線上に配置され、その両側を芸 術館(1894-96) と美術博物館 32)（1899-1906)が囲む構成となってお り、これらはすべてシッケダンツの設計で建てられた。個々の建物 の建設経緯は彼についてのモノグラフ $\left.{ }^{33}\right)$ である程度解明されてい るので、ここでは広場全体の形成の背景について考察する。

英雄広場で最初に計画され、博覧会までに建設された唯一の建物 
は、1893 年の審查委員会案ですでにこの位置の建設がほぼ確定して いた芸術館である。翌 1894 年 1 月に市議会が建設を正式決定し、6 月にシッケダンツが指名された。彼はこの建物をネオ・ルネサンス にギリシア神殿風の大きなエントランスを組み合わせた折衷様式で 設計し、三廊式バシリカのような縦長の平面を採用した。

次に建設が決定したのは建国千年記念碑である。この記念碑の構 想自体は 1870 年代から見られ、1894 年 1 月にこの博覧会のメイン エントランスに建設されることになるまでは、会場からは離れたド ナウ川沿いの丘の上が敷地として想定されていた。建設にはシッケ
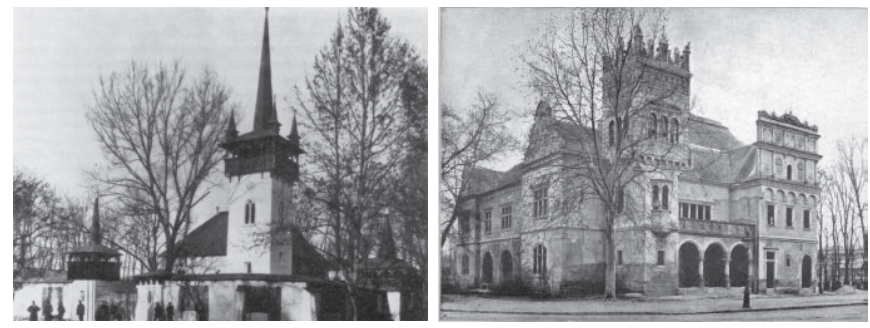

図 11 建国千年祭民俗学部門の教会（左）

図 12 経済・金融・融資館（右）

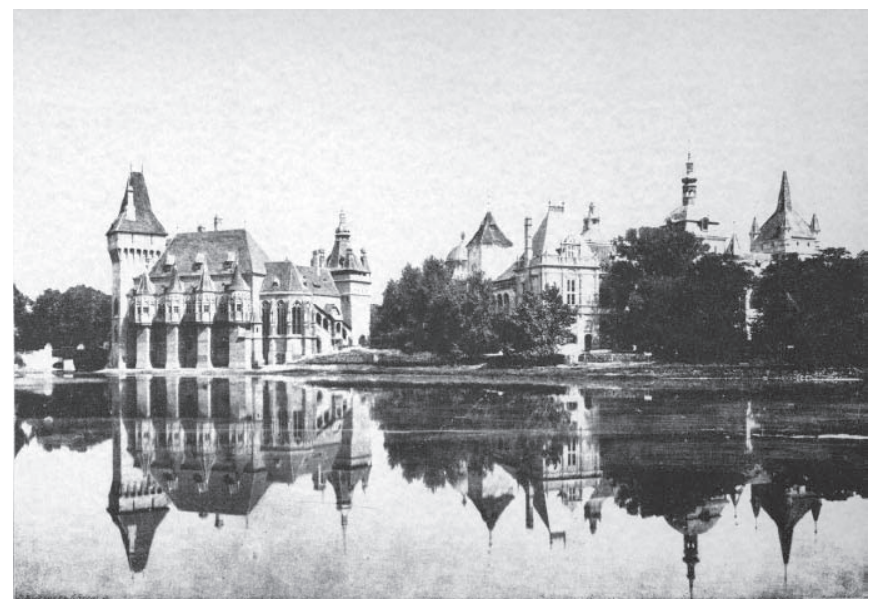

図 13 湖越しに望む歴史館

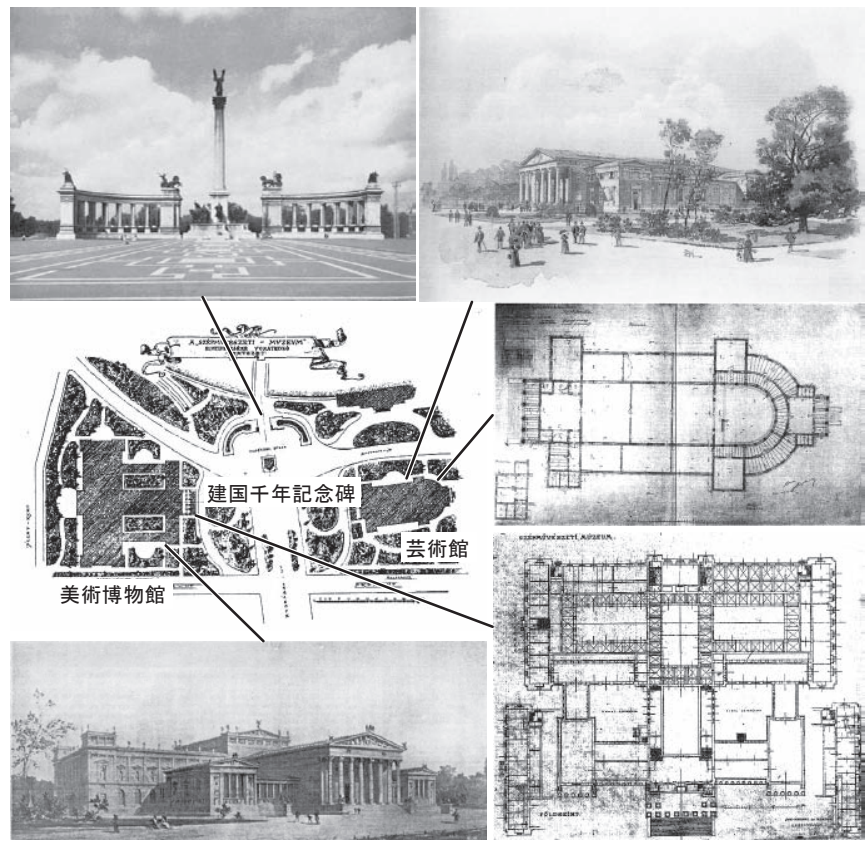

図 14 英雄広場
ダンツと彫刻家ザラ・ジェルジ(Zala György)が指名されたが、その 後建設が博覧会に間に合わないことが判明したために延期され、完 成は第一次世界大戦後になった。

最後に、1894 年にシッケダンツが指名されていたが、当初はヴア 一ロシュリゲトのもっと内部の敷地が想定されていた美術博物館の 建設が 1898 年に決定した。34)シッケダンツは芸術館と似た印象の 新古典主義のファサードを採用して広場に統一感をもたらした。35)

このようにして円形広場に代わるヴァーロシュリゲトの玄関口と して英雄広場が成立したが、会場計画と芸術館の位置が決定した 1893 年の段階で、設計競技審査委員会はこの位置に求心的な構成の 広場は想定してはいなかったと考えられる。審査委員会作成の図(図 8）では、芸術館はシュテファーニア通りを正面にした横長の建物 として描かれているからである。36)

これに対し、シッケダンツが提案した芸術館の縦長の平面 ${ }^{37}$ は、 博覧会場のメインエントランス側に正面を向けていた。この平面の 変更が、この位置に建物が取り囲む閉じた広場が形成されるきっか けになったと考えられる。

アンドラーシ通りの軸線上の建国千年記念碑を中心に左右対称に 見える配置を導入し、通りの終結点として安定感のある造形になっ ている。広場を構成する個々の施設は別個に計画されたものだった が、結果的にこのような整合性のある空間が誕生したことから、シ ッケダンツは当初からここに求心力のある古典的な軸線構成の空間 を作り出とうとしていたのではないかと推測できる。

\section{2 その後の園内整備}

英雄広場の背後の湖に架かる橋と遊歩道は博覧会後も維持された。 さらに、建設中から仮設建築であることを惜しまれていた ${ }^{38)}$ 歴史館 もその姿を留めることになった。1899 年に市が取り壊しを決定した とき、数名の芸術家・建築家により、同じ場所に恒久的な建設手法 で建て直して民俗学博物館か市立博物館とし、英雄広場の美術博物 館、芸術館と共に新たに美術館地区を形成するという提案 39)がなさ れた。これが受け入れられ、1902 年に農業博物館としての再建が決 定し、1904-08 年に改めて恒久的材料で建設された。

その後、湖に架かる橋の延長上にネオ・バロックの大規模な温泉施 設が計画 40)されるなど、英雄広場の背後に公園の賑わいの新たな中 心地区が生まれた。（図 15）一方、シュテファーニア通りや円形広 場周辺は園内の交通路としての重要性を失い、人の流れが減少して

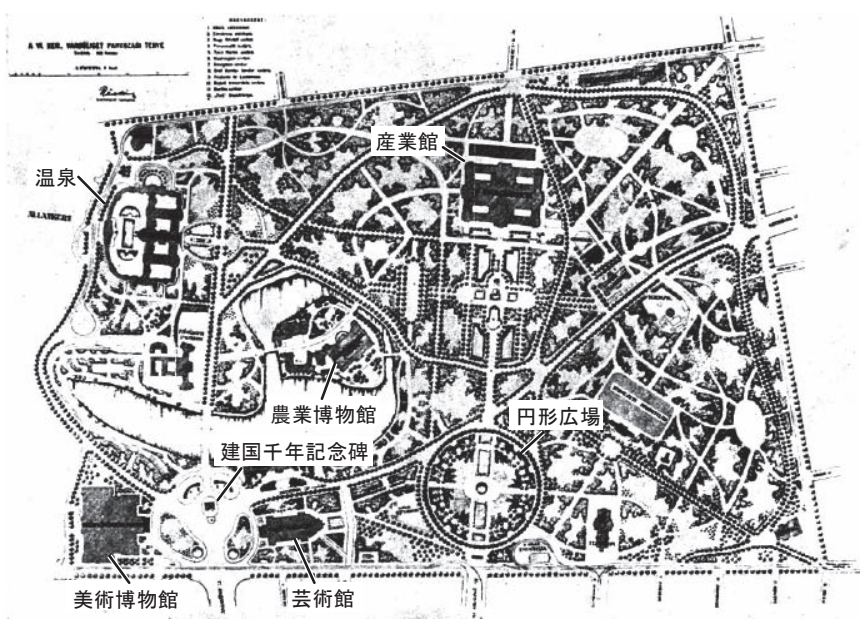

図 15 戦間期のヴァーロシュリゲト 
いる。 ${ }^{41)}$ 第二次世界大戦中の 1944 年の爆撃では農業博物館をはじ めヴァーロシュリゲト内の建物も被害を受けた。これらは戦後修復 されたが、産業館はそのまま取り壞され、42)現在では円形広場も消 滅してしまっている。

博覽会後のヴァーロシュリゲトの整備においては、英雄広場で再 び古典的な構成が導入されたことに加え、広場の背後に公園を直進 して通過する道路も建設されたため、回遊式の構造が維持されたと は言い難い。しかし、会場のメインエントランス付近に園内の中心 区画が形成され、さらに会場を象徵する建物であった歴史館のピク チュアレスクな演出が再現されたことにより、このイベントの記憶 が現在に伝えられている。

\section{19 世紀の博覧会場計画における建国千年祭博覧会の位置づけ}

環状道路による回遊式の動線と湖の中のピクチュアレスクなメイ ンパヴィリオンを採用した建国千年祭博覧会の会場計画は、19 世紀 の博覧会場としては特殊なものであった。これ以前に世界各地で開 かれていた他の博覧会と比較し、建国千年祭博覧会の会場計画の源 泉と新しい点を検証する。

\section{1 回遊式遊歩道と歴史的建造物の引用}

建国千年祭博覧会以前に開かれた主な万国博覧会として、ロンド

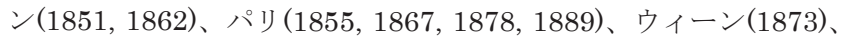
フィラデルフィア(1876)、バルセロナ(1888)、シカゴ(1893)などが 挙げられる。これらの博覧会では鉄やガラスを利用した大建築がメ インパヴィリオンとして会場の中心に据えられていた。時代が下る に従って、メインパヴィリオンの周囲にいくつもの小規模な建造物 が配される例が多くなってくるが、左右対称のメインパヴィリオン や巨大なモニュメントを中心に、その前に軸線を設けるという古典 的な配置計画が原則として受け継がれていた。1 885 年のブダペスト の国内博覧会もこのような先例に倣ったものであったといえよう。

建国千年祭博覧会の会場計画に見られた曲線の動線計画と歴史的 建造物を引用したパヴィリオンの前例を他国の万国博覧会に見出す なら、それはメインパヴィリオン周辺ではなく、会場周縁部の各国 のパヴィリオンが配されていた区画であろう。1867 年のパリ万博で 楕円形の産業宮の周囲に各国の興行的な建物が配置され、それらの 建物の外観には異国情緒が漂っていた。43) 歴史館や民俗学部門の村 などの国内各地の建造物を引用した $\mathrm{C}$ 地区のパヴィリオンもこの文 脈に位置づけることができよう。

ただし、建国千年祭博覧会のパヴィリオンは、単なるエキゾティ シズムを刺激する娛楽施設ではなく、各時代、各地域の建物をなる ベく正確に満遍なく引用して表現しょうとする科学的な態度にも基 づいている。 ${ }^{44}$ 建国千年祭博覧会の会場計画の新しい点は、余興的 な存在であった地区を真面目な展示空間として博覧会の中心に据え、 それを生か寸ための配置を生み出した点にあるといえよう。

\section{2 自然地形を利用したピクチュアレスクな演出}

建国千年祭博覧会とその 3 年前に開催されたシカゴ万博の会場計 画（図 16）は、会場内にある自然の湖と島を利用している点が共通 している。

シカゴ万博の会場は、鉄道の支線が引き込まれて設けられた駅の 前に大広場があり、その前に古典的な軸線構造の空間が展開してい る。軸線の中心には整形された池が配され、その周囲に工業、農業、
機械、運輸、鉱業、電気といった産業展示の大規模なパヴィリオン が整然と並んでいる。一方、その北に隣接する地区には自然の形状

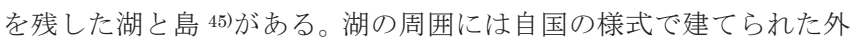
国のパヴィリオンやコロニアル・リヴァイヴァルで建てられた各州 のパヴィリオンが曲線の道沿いに配置されている。軸線構造の整然 とした地区と自然地形の地区が対比的に配された会場構成はパリや ウィーンなどのそれまでの万国博覧会には見られないものであった。 建国千年祭博覧会の会場計画はシカゴ万博（1893 年 5 月 1 日-10 月 30 日）開会直後にほぼ決定している。建国千年祭博覧会関係者 や設計競技応募者がこの大規模な万国博覧会の会場計画に開会前か ら注目しており、自然景観を会場に取り入れる発想もこれを参考に していた可能性は十分に考えられる。

しかし、シカゴの会場の中心となった空間はやはり大広場周辺の 大パヴィリオンが整然と並ぶ地区で、人工的要素を取り入れない湖 の島はそれらの建築的壮大さに対しての引き立て役となることが意 図されていた。46)建国千年祭博覧会において湖の島に会場の中心と なるパヴィリオンを配置して強調し、整然とした軸線構造は 1885 年の博覧会から引き継いだ地区に限定していたのとは対照的である。

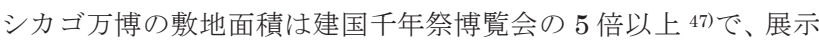
パヴィリオンも大規模なものであった。鉄道で訪れる大量の入場者 を遅滞なく導くためにも整然とした会場構成を中心に位置付けるの が適切であったと考えられる。建国千年祭博覧会の審査委員会案が シカゴ万博を参考にしていたとしても、このような大規模な博覧会 場をそのまま縮小して踏襲するのではなく、規模やテーマの違いを 考慮して適切な解決を導き出したといえよう。

\section{7. 結}

建国千年祭博覧会の会場計画の課題は、1885 年に行われた博覧会 の産業館を中心とした軸線構造を残したまま、新しいメインパヴィ リオンとなる歴史館をより強調することであった。この課題に対し、

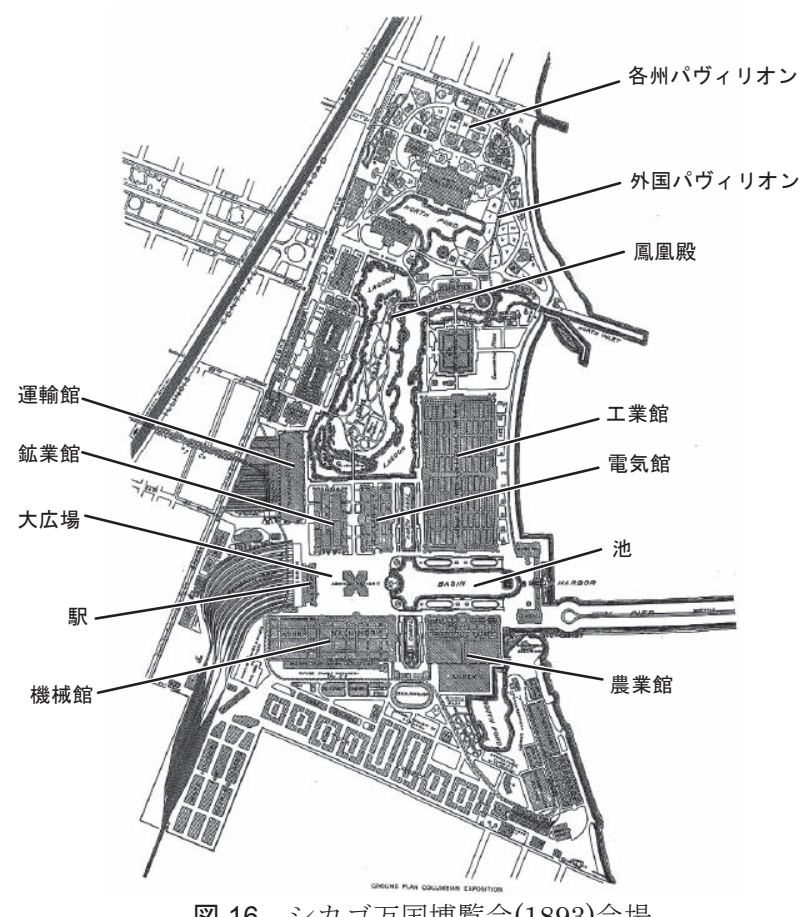

図 16 シカゴ万国博覽会(1893)会場 
設計競技入選各案の構想を取り入れながら審査委員会が作成した案 は、既存の博覧会場の形式にとらわれない、催しの趣旨と敷地条件 に適したものであった。

市内からの大通りの延長上にメインエントランスを設け、その先 の湖を中心区画として整備した結果、エントランス跡地に英雄広場 が誕生し、メインパヴィリオンが再建されるなど、この博覧会で生 まれた空間構造の一部はその後の公園整備にも引き継がれた。

曲線の遊歩道による回遊の構成、歴史的建造物を引用したパヴィ リオン、自然景観を利用したピクチュアレスクな配置計画といった 特徵は当時の各国の万国博覧会では周辺的、従属的にのみ用いられ ていたもので、建国千年祭博覧会において初めて中心的、全体を統 括する原理として採用された。

建国千年祭以後に開かれた博覧会では、歴史的建造物やヴァナキ ユラー建築を模した各国のパヴィリオンがより中心的な役割を担い、 会場の中で強調される例がしばしば見られる。セーヌ川沿いに各国 のパヴィリオンが並べられた 1900 年のパリ万博がその代表例であ る。1931 年に同じくパリで開かれた植民地博覧会 48)では、会場と なったヴァンセンヌの森に植民地の伝統的建築やフランスが建てた 建物を模したパヴィリオンが配置され、回遊することで世界一周の 疑似体験ができるよう演出されていた。建国千年祭博覧会は、この ような傾向を先取りするものであったと捉えることができよう。

注

1）この建国は数年の幅を持って想定されており、当初の 1895 年という目標 より遅れて開催された建国千年祭博覧会の準備状況に合わせ、正式な建 国年のほうが調整された。

2) Magyar Ipar, 1891, no.4 pp.1-3, no.9 pp.1-3, no.10 melléklet pp.1-12

3）王宮の改築(1881-1902)、国会議事堂(1885-1904)など大規模な公共建築の 工事が進行中であった。

4） 1890 年代初頭にはドナウ川に架かる新しい橋梁の建設計画と旧市街対岸 のラージマーニョシュ地区の開発が構想されていたが、この地区を博覧 会場にして開発の起爆剤とする構想もあった。また、建国千年祭博覽会 の開会に合わせて会場へのアクセスとなるアンドラーシ通りの下にヨー ロッパの大陸部では初の地下鉄が開通している。

5) Sisa József, "A Városliget átalakulása az ezredéves kiállítás idején”, Ars Hungarica, 1996/1, pp.57-78

6） 19 世紀の博覧会場計画の展開に関しては、吉田光邦編『図説万国博覧会 史 1851-1942』(思文閣出版, 1985) 、吉見俊哉『博覧会の政治学』（中 公新書，1992）などの著作で分析されている。特にパリ万博の会場計画 に関しては、三田村哲哉, 小林克弘, 中原まり, 『パリにおける博覽会 の変遷に関する研究 1855-1937 年を対象とした配置計画の分析を中心 として』, 日本建築学会計画系論文集, 第 519 号, pp.333-339, 1999.5 で、 2 本の軸線を中心とした古典的構成が踏襲され続けたことが論じられ ている。また、1893 年のシカゴ万博の会場計画については、黒川直樹氏 の一連の建築学会大会学術講演がある。その他、個々の博覧会の建造物、 特に海外の博覧会で建設された日本館については比較的豊富な先行研究 がある。

7) この整備については Thaly Tibor, A 200 éves Városliget, Budapest, 1958, pp.47-58 を参照した。

8）“Az országos kiállítás”, Magyar Ipar, 1882, p.295. 産業館以外に芸術館 （建国千年祭博覧会では衛生館に転用）、「国王のパヴィリオン」(この 博覽会後に喫茶店に転用され、建国千年祭博覽会会期中もそのまま営業 が続けられた）が恒久的建造物として建てられた。

9) Sisa, Op. cit., pp. 59-61

10) Magyar Ipar, 1891, no.4 p.1

11) "Die Millenniums-Ausstellung", Bauzeitung für Ungarn, 1893, p.43. 歴史館設計競技の提出期限は会場計画より遅い 4 月 30 日であった。
12) “Az ezredéves kiállitás", Épító Ipar, 1893, pp.36-37

13）歷史館 $\left(3000 \mathrm{~m}^{2}\right)$ 、民俗学・家内産業展示館 $\left(1500 \mathrm{~m}^{2}\right)$ 、公共教育館 $(1500 \mathrm{~m}$ $\left.{ }^{2}\right)$ 、衛生館 $\left(800 \mathrm{~m}^{2}\right)$ 、本部館 $\left(1000 \mathrm{~m}^{2}\right)$ 、農業生産展示館 $\left(4500 \mathrm{~m}^{2}\right)$ 、造園 館 $\left(1000 \mathrm{~m}^{2}\right)$ 、林業館 $\left(1000 \mathrm{~m}^{2}\right)$ 、ワイン・酒造展示館 $\left(1000 \mathrm{~m}^{2}\right) 、$ クロチ ア・スラヴオニア展示館 $\left(800-1000 \mathrm{~m}^{2}\right) 、$ 鉱業・製鉄業・建設材料展示館 $\left(2000 \mathrm{~m}^{2}\right)$ 、交通展示館 $\left(3500 \mathrm{~m}^{2}\right)$ 、機械館 $\left(10,000 \mathrm{~m}^{2}\right)$ 、ボイラー・機械修 理館 $\left(400 \mathrm{~m}^{2}\right)$ 、警察本部庁舎 $\left(350 \mathrm{~m}^{2}\right)$ 、警備庁舎 $\left(400 \mathrm{~m}^{2}\right)$ 、消防署・住居・ 倉庫 $\left(400 \mathrm{~m}^{2}\right) 、$ 、クークルーム・洗面所・鉄道集荷場・現金警備の建物 $\left(400 \mathrm{~m}^{2}\right)$ 、博覽会小食堂 $\left(800 \mathrm{~m}^{2}\right)$ 、式典館 $\left(5000 \mathrm{~m}^{2}\right)$ がプログラムで指定さ れていた。

14）設計競技の審査員は商業大臣ルカーチ・ベーラが指名した。博覧会実施 委員長ネーメト・イムレ(Németh Imre)以外に博覧会主任技師、貴族、国 会議員、副市長、土地担保貸付銀行頭取、首都公共事業評議会副委員長、 建築家、土木技師が名を連礼ていた。(“Die Millenniums-Ausstellung”, Bauzeitung für Ungarn, 1893, pp.90-91)

15) 審査評は“A millenniumi kiállítás területének elrendezésére hirdetett pályázat alkamával díjazott tervek", Épító Ipar, 1893, pp.119, 123, 127 に掲載されている。

16）1868-78 年にかけて掘削された被圧地下水を利用した施設で、現在のセ一 チェニ温泉の前身である。シッケダンツ案もこの温泉施設を敷地に含め ているが、取り壊しは避けている。

17）歷史館設計競技は特定の敷地を前提としたものではなかったため、応募 案の多くは左右対称の長方形平面の建物を提案しており、入選案のうち シッケダンッ案のみが池の中という具体的な敷地を想定していた。(“A millenniumi kiállítás történelmi csarnokára hirdetett pályázat alkalmával díjazott tervek", Épító Ipar, 1893, p.143）その後、彼の提案 した設計コンセプトと敷地条件に基づいて第二回設計競技が行われた。 （ただし、この設計競技で入選したのは別の建築家であった。）

18) “A millenniumi kiállítás területének beosztása”, Épító Ipar, 1893, pp.113-115. B 地区を放革したのは、市民のために公園も残寸ためとして いる。

19) 建築家のツィグレル・ジェーゼー(Czigler Győzó)、ハウスマン・アラヨ シュ(Hauszmann Alajos)、カウゼル・ヨージェフ(Kauser József)、都市 計画家のレヒネル・ラヨシュ(Lechner Lajos)、工業連盟理事のゲッレー リ・モール(Gelléri Mór)が構成員であった。中でも当時王宮や最高裁判 所などの重要な公共建築を手掛けておりハウスマン(1847-1926)、1870 年代からブダペスト旧市街整備計画やセゲド市の洪水復興を指揮してい たレヒネル(1833-97)は、当時のハンガリー建築界の中心的存在であった。

20) "Die Millenniums-Ausstellung", Bauzeitung für Ungarn, 1893, pp.114-116

21) Bauzeitung für Ungarn, 1893, p.145; Épító Ipar, 1893, 42-iki rajzmelléklet; Építészeti Szemle, 1893, p.301

22)この村は、1892 年に民俗学者のザントゥシュ・ヤーノシュ (Xantus János) が提案したものであった。博覧会実施委員会がこれを承認し、民俗学部 門は建築・内装(家財道具) ・衣装の 3 項目の展示を行うことになった。 (Szemkeő Endre, "Bevezetés", Jankó János, A millenniumi falu, Budapest, 1989, pp.7-15)

23）この位置の芸術館建設は設計競技開催中の 2 月から検討され始めていた。 6 月 5 日、博覧会実施委員会は 4 月 5 日のブダペスト市議会の要請に返答 し、博覽会場に恒久的な建物を建設しない条件について、芸術館を例外 とするよう、また、橋とその延長上の道路も市民の休養に供する設備と して会期後も残寸よう求めている。“A millenniumi kiállítás területének beosztása”, Épító Ipar, 1893, pp.113-115

24) “Az ezredéves kiállítás területe”, Vasárnapi Újság, 1893, p.407

25) “Millenniumi kiállítás”, ÉpítóI Ipar, 1894, p.465. 広げられた地区は軍事 関連の展示に充てられた。

26) 漁業館、河川航行・整備館がエントランス右手の湖岸に配置された。

27) Bálint Zoltán, Az ezredéves kiállitás architekturája, Bécs, 1897, p.33. 1893-94 年に島の岸辺を敷地として国王館の設計競技が 2 回行われた(第 1 回: “A mû- és középítési szakosztályok tervpályázata”, Magyar Mérnök- és Építész-Egylet heti értesítóje, 1893, p.207. 第 2 回 : “Az 1896-iki ezredéves országos kiállítás királypavillonjának tervezésére másodízben kitűzött pályzatot bíraló bizottság jelentése", Épító Ipar, 
1894, pp.508-509）が、どの案も採択されなかった。

28) 現ルーマニアのトランシルヴァニア地方クルージュ・ナポカ市 (Cluj-Napoca)西方一帯の地域名。ハンガリーにおける民芸や民族学への 注目はこのカロタセグ地方から始まっており、当時ハンガリーの農村を 代表する地方とみなされていた。

29) “A kiállítási falu temploma”, Vasárnapi Újság, 1896, p.8

30) "Az ezredéves kiállítás kereskedelem-, pénz- és hitelügyi csarnoka", Építő Ipar, 1896, p.227

31) 現スロヴァキアのプレショフ(Prešov)の商家、ケジュマロク(Kežmarok) の鐘楼などの形状が認められる。

32) 臨時の展覧会の開催を目的とした芸術館(Múcsarnok)に対して、この美術 博物館(Szépmúvészeti Múzeum)は貴族の美術コレクションや新たに購 入した作品をもとに設立された常設の施設であった。

33) Gábor Eszter, Verő Mária, ed., Schickedanz Albert 1846-1915, Budapest, 1996. 展覧会カタログとして編纂されたものである。

34) 1899 年に設計競技も行われたが、最終的に採用されたのは 1 位のペッ ツ・シャム(Pecz Samu)の案ではなく 2 位のシッケダンツの案であった。 シッケダンツ案のほうが動きの自由度がより高いという政府の委員の助 言で教育大臣ヴラシッチ・ジュラ(Vlasics Gyula)が決定したと報じられ ている(Biebauer István, “A Szépmúvészeti Múzeum”, ÉpítőIpar, 1913, pp.1-3，13-16)が、当初からシッケダンツが指名されていた経緯とも関係 があるのかもしれない。

35）ただし、図 14 に見るように、美術博物館の平面は横長の建物二棟を前後 に並べ、中央の吹抜けホールと左右の通路で繋いだもので、芸術館とは 全く異なっている。また、二つの建物は正確に向かい合ってもいない。

36) この建設位置について、当時「我が国では公共建築を外れた場所になる ベくうまく隠すように努力している」と皮肉を述べる建築評論家もいた。 (Kolbenheyer Gyula, "A millenniumi kiállítás végleges helyszinrajza", Magyar Mérnök- és Építész-Egylet heti értesítóje, 1893, p. 124)

37) バシリカの平面計画を美術館に応用する発想は、1866-76に建てられたべ ルリンのナツィオナルガレリーにも見られるため、これを参照にしてい た可能性も考えられる。

38) "Látogatás a kiállítási területen", Építő Ipar, 1894, p.531

39) "A történelmi épület-csoport ügye”, Mücsarnok, 1899, pp.247-250. そ の中にはシッケダンツも名を連ねている。

40）市の技術局が 1906 年に長円形の広場を取り囲むように温泉、ホテル、温 室を配置する構想を立てたが、実現(1909-13)したのは温泉だけであった。

41）例えば、円形広場は 1916 年にエルジェーベト王妃追悼記念碑の候補地に 選ばれているが、その敷地に求められたのは「閑静な」巡礼地であるこ とだった。

42) Thaly, Op. cit. , pp.134-135

43) 吉見, Op. cit., pp.71-72

44)このような建国千年祭博覧会の個々の建物の計画経緯と、19 世紀の博覧 会パヴィリオンの展開とハンガリーの建築史におけるその位置づけにつ いては、稿を改めてより詳細に論じる予定である。歴史館の設計経緯に ついては拙稿『ハンガリー建国千年祭(1896)歴史館設計過程における文化 財に対する認識の変化』（日本建築学会大会学術講演梗概集, 2006, pp.209-210）でも言及している。

45）日本の「鳳凰殿」が建てられることになるウッデド・アイランドである。

46) 黒川直樹『1893 年シカゴ世界博覧会の景観計画と F.L.オームステッド』 （日本建築学会大会学術講演梗概集，1996,pp.451-452）ちなみに、建国 千年祭博覧会でも、ヴァーロシュリゲトに会場が決定した段階では、植 栽を維持するために、島の上には決して大きな建物を建てないよう市か ら求められていた。(Bálint, Op. cit., p.10)

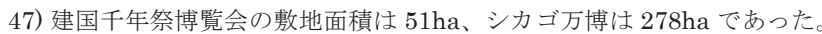

48)このパリ植民地博覧会の敷地選定と配置計画、その後への影響について は Morton, Patricia A., Hybrid Modernities: Architecture and Representation at the 1931 Colonial Exposition, Paris, Cambridge, Mass., 2000 (モルトン, パトリシア 長谷川章（訳）『パリ植民地博覧 会 — オリエンタリズムの欲望と表象』, 2002,pp.121-166)が詳しい。
図 2 Budapest régi térképei II., Budapest, 2005, DVD

図 3 A budapesti országos kiállítás madártávlatból, Budapest, 1885

図 4-8 Épító Ipar

図 9 Bálint, Op. cit.

図 10 Rózsa György, Budapest legszebb látképei, Budapest, 1995

図 11-13 Az ezredéves Magyarország és a milléniumi kiállitás, Budapest, 1896

図 14 (英雄広場) Borsos Béla, et al., Budapest éptészettörténete, városképei és múemlékei, Budapest, 1959

図 14 (それ以外) Gábor, Verő, Op. cit

図 16 Bancroft, Hubert Howe, The book of the fair, Chicago, 1893

（2009年12月 9 日原稿受理，2010年 4 月30日採用決定）

図 1, 15 Thaly, Op. cit. 